\title{
A genuinely free press: The challenges for the Pacific
}

Pacific journalism must be able to thrive in an environment which allows debate and discussion, such as through a Press Club where speakers are invited and issues can be discussed off the record. A robust discussion sometimes frees up the logjams in thinking.

\section{By SHAISTA SHAMEEM}

IT WASon this very campus, in the mid 1970s, in 1973 to be precise, that I first learnt about the power of the media. Unlike most of my fellow students I was not particularly politically inclined, and the scandal at that time gripping the United States about the doings of President Nixon had passed me by. My political science major friends, endlessly and boringly discussed the events in the US, but I was more interested in other trivial pursuits that first year university students in the 1960s and 70s were inclined to explore, usually to the detriment of their studies.

That was the case, until the Woodward and Bernstein story about Watergate, All the President's Men, hit the USP Bookstore, followed by the movie. The book became compulsory reading for every student, whether or not they understood, or indeed cared about, the finer points of American Government. The rather sexy title of "Deep Throat" as the mole giving the two journalists the inside story of one of the most fascinating periods of American political history could not be resisted. Watergate probably gave birth to more journalists than ever before. Everyone wanted to tell the story that could bring down a government.

And that is the point, really, about journalism and governance. The media has always had an extraordinary relationship with governments. If you open any newspaper today, or indeed listen to the radio or if you watched TV last night, 


\section{BICULTURALISM}

you will find that at least 75 percent if not more news items will be about government; or about what some public official has said; or what some ministry has done; in fact more likely about what they haven't done. The media seems to find a devilish delight in exposing the foibles and failures of public servants and parliamentarians. It seems to relish every scandal, sniff out every discrepancy and flagellate to death every inconsistency.

These are just the news stories. The editorials are much much worse. They are the epitomy of embarrassment for any luckless public servant or official who happens to have made the mistake of attracting the attention of some editor or other. Editors in Fiji do not mince their words; they shoot from the hip and seem to embrace the words "publish and be damned" as though they were supposed to be taken literally.

Many of you are journalism students celebrating World Media Freedom Day today. I advise you to take a leaf out of the newspapers and magazines of Fiji's media if you want to be successful in your chosen profession. Despite all the upheavals of our recent political past, despite the extraordinary difficulties of trying to keep the public informed with timely and accurate information on a day to day basis, the Fiji media have come out with flying colours. Of course I don't agree with everything they say and I certainly find some columns extremely tedious on occasion, but today of all days, we must congratulate the Fiji media for persistently and steadfastly enabling us, the ordinary citizens, to exercise our right to freedom of information.

The coordinator of your programme, David Robie asked me to speak to you today on "Human rights and the Media: the challenge for a genuinely free press in the Pacific", and indeed on a whole host of other matters which will take me at least a month to delve into. But the notion of a genuinely free press is an important one because it raises a number of other related questions such as, well what is a genuinely free press? This is a very difficult concept because to be genuinely free, an institution or indeed a person must not be restricted by anyone or anything. Is there such a thing as a genuinely free press? Probably not. Newsmedia outlets usually come in three forms, newspapers, radio television; of course we have magazines, and now the internet which perhaps is the only free press there is, not being subject to the restrictions that the other more conventional forms of media are. But the notion of a free press cannot be conceptualised in a world where huge print media conglomerations exist, where television is dependent on someone else's satellite or indeed satellite licence, and where radio is often owned by government or private companies who 


\section{INDEX}

depend on advertisements for their very survival. Indeed cynics might say that 21 st century media operations are the very opposite of democracy, owned as they are by huge companies enjoying monopolistic advantages and provided by governments with licenses to operate without competition for long periods of time. It is very difficult to talk of a genuinely free press in these circumstances.

However I am encouraged not by the notion of a "free press", but by the idea of an independent cadre of journalists, "free journalists" in fact. An institution is only as good as the people making it work, and therefore I believe that independent thinking in journalism and the ability to translate this for public consumption and information is what is meant when people talk about a free press.

What is then the relationship between independent journalism and human rights?

Let me briefly tell you about human rights. This is a very interesting concept defined and developed in a legal framework after World War II, in fact as a result of the horrors of the Holocaust, but really is a concept that is universal throughout humanity. When people ask me about the definition of human rights, I tell them that it is merely another name for justice and fairness, concepts that are present in all societies, small and large, all over the world. There are some fundamental human rights principles that we all know and understand; they are: the right to one's own beliefs and opinions; the right to be treated the same as another person, in other words the right to equality; and the right to justice. All other human rights have been developed around these fundamental principles.

But before I go into the details of rights per se, let me just explain to you what the job of the Fiji Human Rights Commission is. The Human Rights Commission is a constitutional body, established by section 42 of the 1997 Constitution to look after human rights issues in Fiji. It is a unique institution which did not exist prior to the 1997 Constitution, even though rights andfreedoms were included in the 1970 and 1990 Constitutions of Fiji. The commission is mandated to first of all educate the public about human rights in the United Nations instruments, secondly, it is mandated to advise Government about its human rights responsibilities to the people of Fiji and also its responsibilities internationally to protect and defend human rights. Thirdly, the Commission has the responsibility to investigate allegations of human rights abuses, to try and bring the parties together, and if that fails, to go to court, to let the court decide whether a human rights abuse or violation has taken place. So, as you can see, 
the Human Rights Commission has a lot of responsibility to ensure that human rights are protected and promoted in Fiji.

Now what are the human rights laws of the country; in other words, what is the commission empowered to protect and promote. The Constitution of Fiji, in Chapter 4 mainly, contains a comprehensive set of rights, derived from the Universal Declaration of Human Rights. There are 22 sections detailing these rights in full, but we can divide them into categories of rights for easy reference. Firstly, there are the "rights to" provisions, which give people rights such as "the right to life", the right to freedom of conscience, religion and belief, the right to form and join trade unions, right to personal liberty, access to courts, right to privacy, right to vote by secret ballot, right to equality and so on. Secondly, there are the "Freedom of" rights, such as the freedom of movement, freedom of association, freedom of assembly, all these rights. Finally there are the "Freedom from" rights, that is, freedom from cruel degrading treatment or punishment, freedom from unreasonable searches and seizure, freedom from forced labour and so on. Every person and every community in Fiji is protected by law from an infringement by Government, and in some circumstances by private individuals or institutions, of these rights and freedoms.

These legislated rights are not unique to Fiji. Every other Pacific Island nation with a supreme Constitution such as ours has exactly these same rights. Also New Zealand has a Bill of Rights Act which is not supreme but is given great significance by the courts there. And Australia too has a similar set of rights and freedoms. These rights and freedoms do seem to have universal application now and indeed international courts and tribunals have been set up to cater for rights violations if national governments are unable to deal with them.

This brings me to the human rights issues facing Fiji at this present moment. The establishment of the commission has encouraged the public to come forward with their complaints. This was not available to people before 1999 . The commission has dealt with a wide variety of complaints since 1999, for example,complaints against public officials, including the police, army and prisons officials, complaints about public access for people with disabilities, complaints about racial and sex discrimination, including sexual harassment at work, complaints about work conditions; in fact, I can say with some confidence that the commission has dealt with just about every single right protected in Chapter 4 of the Constitution. In most cases we have been able to resolve these 


\section{INDEX}

complaints through conciliation conferences, and in a number of cases we have also gone to court when we saw that conciliation was going no-where.

Since 2000 we have also dealt with complaints from people living in certain areas such as Muaniweni and Dawasamu about the racially-tinged nature of the terrorism they suffered after May 19, and Wansolwara has written about this, most accurately I might add, and we continue to assist the Ministry of Reconciliation and the Police with their efforts in the affected areas.

With respect to the rest of Pacific, the issues facing the Solomon Islands and Papua New Guinea come to mind, but the Fiji Human Rights Commission is a national body and we have no mandate to look at how these other countries will define and resolve their own human rights problems they face. However, we can say the Fiji Commission is committed to assisting these countries to form their own national human rights institutions when they are ready, and indeed we have already had some positive talks with Vanuatu's Ombudsman in this regard. The Fiji Commission is the first in the Pacific Island states and it is only natural that we are seen to be in a position to provide this assistance. Human Rights Commissions are a relatively recent development, showing governments' commitment to human rights because they are funded by government to be independent and autonomous in their provision of human rights services to the public.

The media's role is critical in the endeavour to protect human rights; not only to promote the rights of citizens but also to protect its own independence. The media can undertake this two-fold responsibility in a consistent way. Informing the people of decisions that may affect them is a very important responsibility. Accuracy in reporting, thoughtfulness in the analysis, consideration for both sides of the story but at the same time knowing right from wrong, are all componants of a story of quality. A story which has been thoroughly sensationalism for its effect on the public. I know it is difficult sometimes to do a good job as deadline approaches; and all of us have winged it from time to time. You can ask Robert Keith-Reid and Seona Smiles, who trained me during my cadet reporter days with The Fiji Times, about the number of times they threw my copy back at me for not doing enough research or not asking the right questions. In those days we did not have a journalism programme to train us; you are fortunate indeed.

But anyone can learn the technical skills of journalism; that's the easy part. The hard part is to understand the world that you are writing about. I am sure we all have some senior scribe or other that we admire greatly. If you don't, then 124 PACIFIC JOURNALISM REVIEW 82002 


\section{A good journalist is someone with such an in-depth under- standing of the issues that the} words, though simply written, leap out from the page. A human rights story is one where analysis and reporting are a unique combination.
I suggest you find someone whose writing you like. I know that my definition of a good journalist is someone with such an in-depth understanding of the issues that the words though simply written, virtually leap out from the page. A human rights story isn't just a human interest story. A human rights story is one where analysis and reporting come together in that unique combination which has the power to transform the reader by reaching his or her consciousness. By transforming the reader's ideas about events, you will inevitably allow that person to contribute to transforming the world.

I started my speech today by talking about Watergate and I linked this with journalists' ability and indeed some would say responsibility to transform society through the power of writing. Human rights advocates also make it their business to change society for the better so that the rights of people, both individuals and groups, can be protected. A journalist wearing human rights spectacles would have an edge over other journalists but the question is, can anyone be bothered with the effort? How many journalists during the 2000 events in Fiji actually thought about the human rights aspects of these events? Should they consider every crisis in human rights terms? It's an individual decision of course and not every journalist can cope with that responsibility. However, it is a challenge you will all have to face sooner or later in your work, as have other journalists before you; a good example is the journalist who exposed the My Lai massacre in Vietnam, which turned the tide in the US against the Vietnam War, or the many unsung heroes of the press corps who have lost their lives covering wars and other troubles all over the world, the most recent casualty being David Pearl of the Wall Street Journal whose body I think still has not been recovered.

I was asked by David Robie to be wide-ranging in my address to you and I hope I haven't taken this too literally today. Perhaps, just so that there can be 


\section{INDEX}

something to report, I should make the following important points about the relevance and significance of World Media Freedom Day from a human rights perspective:

First, that media freedom should be seen as a standard to be attained rather than a blueprint for dogged pursuit.

Second, journalists can help to create press freedom by being free and independent thinkers, and seriously developing the capacity for research.

Thirdly, journalists should read widely on topics such as philosophy, politics, sociology and the sciences. This will bring depth to the writing, which in turn informs the reader in a much more comprehensive way.

Fourthly, journalism must be able to thrive in an environment which allows debate and discussion, such as through a Press Club where speakers are invited and issues can be discussed off the record. A robust discussion sometimes frees up the logjams in thinking.

Perhaps the journalism programme at USP can initiate such a forum, as it has initiated so many other good ideas.

Finally, journalists should take their craft seriously, and fine-tune it as though it were a delicate instrument, to be polished and warmed up before giving it up to the public. The public will respond more positively to a wellwritten story and the effect of that story will be far-reaching. In human rights terms, this means giving the people an opportunity to be fully and accurately informed by the technique of writing as well as its contents.

$\square$ Dr Shaista Shameem is director of the Fiji Human Rights Commission and a former Fiji Times journalist. This was her keynote speech at the World Media Freedom Day seminar organised by the University of the South Pacific on 3 May 2002.

sshameem@humanrights.org.fj 